TITLE:

\title{
Estimation of carbon biomass and community structure of planktonic bacteria in Lake Biwa using respiratory quinone analysis
}

\section{$\operatorname{AUTHOR(S):~}$}

Takasu, Hiroyuki; Kunihiro, Tadao; Nakano, Shinichi

\section{CITATION:}

Takasu, Hiroyuki ... [et al]. Estimation of carbon biomass and community structure of planktonic bacteria in Lake Biwa using respiratory quinone analysis. Limnology 2013, 14(3): 247-256

ISSUE DATE:

2013-08

URL:

http://hdl.handle.net/2433/190410

\section{RIGHT:}

The final publication is available at Springer via http://dx.doi.org/10.1007/s10201-0130402-3; この論文は出版社版でありません。引用の際には出版社版をご確認ご利用くだ さい。; This is not the published version. Please cite only the published version. 
2 Estimation of carbon biomass and community structure of planktonic bacteria in Lake

\section{Biwa using respiratory quinone analysis}

4

5

6

$7{ }^{1}$ Center for Ecological Research (CER), Kyoto University, Hirano-cho 2 chome, 509-3, Otsu,

Hiroyuki Takasu ${ }^{1}$, Tadao Kunihiro ${ }^{2,3}$ and Shin-ichi Nakano ${ }^{1 *}$

Shiga 520-2113, Japan

${ }^{2}$ Center for Marine Environmental Studies (CMES), Ehime University, Bunkyo-cho 2-5, Matsuyama 790-8577, Ehime, Japan

${ }^{3}$ Department of Ecosystems Studies, Royal Netherlands Institute of Sea Research (NIOZ), Korringaweg 7, 4401 NT Yerseke, The Netherlands

*Correspondence to: Shin-ichi Nakano: Mailing address: Center for Ecological Research (CER), Kyoto University, Hirano-cho 2 chome, 509-3, Otsu, Shiga 520-2113, Japan.

Phone and Fax: +81-77-549-8239, +81-77-549-8201

E-mail:nakano@ecology.kyoto-u.ac.jp

Running title: Carbon biomass and community structure of bacteria in Lake Biwa 


\section{Abstract}

The relationship between bacterial respiratory quinone (RQ) concentration and biomass was assessed for Lake Biwa bacterial assemblages to evaluate the utility of bacterial RQ concentration as an indicator of bacterial carbon. Biomass estimated from RQ concentration correlated well with that from cell volume, indicating that RQ concentration is an appropriate indicator of bacterial biomass. The estimated carbon content per RQ content (carbon conversion factor) of bacteria was $0.67 \mathrm{mg} \mathrm{C} n m o l ~ R Q^{-1}$. Bacterial carbon biomass, which was estimated from RQ concentration using the conversion factor, ranged between 0.008 and $0.054 \mathrm{mg} \mathrm{C} \mathrm{L}^{-1}$ (average: $0.025 \mathrm{mg} \mathrm{C} \mathrm{L}^{-1}$ ) at $5 \mathrm{~m}$ depth and between 0.010 and $0.024 \mathrm{mg} \mathrm{C}$ $\mathrm{L}^{-1}$ (average: $0.015 \mathrm{mg} \mathrm{C} \mathrm{L}^{-1}$ ) at $70 \mathrm{~m}$ depth. Ubiquinone-8-containing bacteria dominated the epilimnion and hypolimnion. Compared to the conventional image analysis, the bacterial RQ analysis is a less laborious way for simultaneous determination of bacterial biomass and community. 


\section{Introduction}

Bacteria are numerically important components in the water columns of freshwater and marine systems. Many studies have demonstrated that the efficiency of recycling of matter depends on the bacterial metabolic activity, growth rate, and biomass (reviewed by Ducklow 2000; Azam and Malfatti 2007). As a result, bacteria are thought to be the major players in mineralization and biogeochemical organic matter transformations. Previous studies have reported that natural bacteria differ in terms of size distributions (Nagata 1986), metabolic state (Gasol et al. 1999), dissolved organic matter (DOM) utilization (Kirchman et al. 2004; Yokokawa and Nagata 2010), and growth rate (Yokokawa et al. 2004).

Since natural bacterial assemblages consist of various subgroups in terms of ecological and biogeochemical features, the phylogenetic and functional diversity of bacteria has been investigated in marine and freshwater environments. A majority of previous studies have discriminated bacterial communities on the basis of the 16S rRNA gene and with dramatic development of molecular biological techniques, the phylogenetic and functional diversity of bacteria has been revealed (Glöckner et al. 1999, 2000; Kirchman et al. 2004; Yokokawa et al. 2005). However, phylogenetically distinct bacterial groups do not always correspond to functional groups in matter cycling (Langenheder et al. 2005, 2006). The information about physiological discrimination of bacterial groups such as cellular components and nucleic acid content is quite limited, and the utility of physiological discrimination in bacterial community in the carbon cycling has not yet been fully understood.

Bacterial biomass is the fundamental parameter that directly links estimations of production, growth efficiency, and bioenergetics of the bacteriovores. Image analysis of bacterial cell volume is the most common tool used to estimate bacterial biomass, and this method has improved over several decades (Nagata and Watanabe 1990; Blackburn et al. 
1998; Posch et al. 2009). However, image analysis is time-consuming, laborious, and involves many technical difficulties such as staining with fluorescent dyes (Posch et al. 2001; Straza et al. 2009) and artificial errors in cell volume measurement (Nagata and Watanabe 1990). A less time-consuming, less laborious, and more accurate method for bacterial carbon biomass measurement is needed to evaluate bacterial contributions to matter cycling in aquatic systems.

Respiratory quinone (RQ), including ubiquinone (UQ) and menaquinone (MK), are components of the electron transport chain located in the bacterial plasma membranes. Bacteria have diverse respiratory systems, and they can use more than 20 inorganic or organic redox pairs for energy production ( $\mathrm{Li}$ 2010). Individual RQs differ in their preference for the electron acceptor for energy metabolism. In general, UQs are mainly produced for the oxygen and nitrate respiratory types because of the large midpoint potential between UQs and $\mathrm{UQH}_{2}$ $(+0.122 \mathrm{~V})$, whereas MKs $(-0.074 \mathrm{~V})$ are mainly produced for the respiratory types with low-potential electron acceptors. As individual bacteria has only 1 dominant RQ type, RQs are potentially useful as specific biomarkers for discriminating between the biomass of bacterial subgroups with different types of energy metabolism (Collins and Jones 1981; Hedrick and White 1986; Villanueva et al. 2007). RQs have been shown to be appropriate biomarkers for tracing the bacterial biomass in various environments (Hedrick and White. 1986; Hiraishi 1999), as they are membrane lipids and not storage lipids, and undergo rapid degradation within hours or days after cell death (Hiraishi and Kato 1999). As these biomarkers directly indicate the bacterial biomass, improvement in the chemical determinations of bacterial biomass may provide a less time-consuming and more accurate method for estimating bacterial biomass in aquatic systems.

RQ typing, which discriminates bacterial subgroups based on differences in energy metabolism, may be appropriate for identifying useful functional units in ecological 
matter-cycling studies. However, there is not much clarity on whether bacterial RQ concentration can be used as an indicator of bacterial biomass in water columns, although bacterial quinone concentrations in soil environments have displayed linear relationships with bacterial carbon concentration (Saitou et al. 1999) and cell abundance (Hiraishi et al. 2003). Thus, our major goal was to examine the utility of planktonic bacterial RQ analysis as a reliable method for carbon biomass estimation in Lake Biwa. Moreover, we also evaluated the reliability of RQ-based bacterial discrimination as a tool for planktonic bacterial community analysis.

\section{Materials and Methods}

Study site and sampling

Lake Biwa is a large (surface area, $674 \mathrm{~km}^{2}$ ), deep (maximum depth, $104 \mathrm{~m}$ ), monomictic, and mesotrophic lake located in the central part of Honshu Island, Japan. The sampling station for the present study was a pelagic station $\left(35^{\circ} 12^{\prime} 58^{\prime \prime} \mathrm{N}, 135^{\circ} 59^{\prime} 55^{\prime \prime} \mathrm{E}\right.$; maximum depth 73 m), in the north basin of the lake. Samples were collected every month from June 2010 to March 2011. Depth profiles of water temperature were determined using a CTD probe (SBE 911 plus; Sea Bird Electronics). Samples were collected from 2 distinct layers at depths of 5 $\mathrm{m}$ (the epilimnion) and $70 \mathrm{~m}$ (the hypolimnion) with a 10-L acrylic water sampler and poured into 5- or 10-L polyethylene bags for RQ analysis. The samples were also collected with 5-L Niskin X bottles (General Oceanics) and poured into $500-\mathrm{mL}$ polycarbonate bottles washed with $1.2 \mathrm{M} \mathrm{HCl}$ for analyses of chlorophyll $a$, dissolved organic carbon (DOC), and particulate organic carbon (POC). Bacterial enumeration was performed by taking $200 \mathrm{~mL}$ of the water sample in a polypropylene bottle and fixing immediately with glutaraldehyde at a final concentration of $1 \%$. 


\section{Bacterial enumeration}

We used $2 \mathrm{~mL}$ of the fixed water sample for enumerating the bacteria. Bacterial cells were stained with DAPI, filtered through black polycarbonate filters having a pore size of $0.2-\mu \mathrm{m}$ (Millipore), and counted using an epifluorescence microscope (BX60, Olympus) under ultraviolet excitation (Porter and Feig 1980). At least 20 fields were randomly inspected in triplicate, and more than 300 bacterial cells were counted for each replicate. The length and width of each bacterial cell were measured for more than 200 bacterial cells in each sample with image analysis software (Image J; National Institute of Health). Images were captured at a magnification of $1000 \times$ with a CCD camera (ORCA-ER; Hamamatsu) equipped with an epifluorescence microscope. Bacterial cell volume was calculated as described by Nakano and Kawabata (2000).

\section{Chemical variables}

Samples for DOC were filtered through $0.2-\mu \mathrm{m}$ polycarbonate filters (Whatman) that had been washed with 1.2 M HCl. DOC concentrations were determined using a total organic carbon analyzer (TOC-5000A; Shimadzu).

On the other hand, to determine chlorophyll $a$ concentration, $100 \mathrm{~mL}$ to $200 \mathrm{~mL}$ of water samples were filtered through $0.2-\mu \mathrm{m}$ polycarbonate filters (Whatman) and analyzed with the $N^{\prime} N$-dimethylformamide method (Moran and Porath 1980) using a fluorescence spectrometer (RF-5300PC; Shimadzu).

POC measurements were carried out between September 2010 and March 2011. Glass fiber filters of $0.3 \mu \mathrm{m}$ nominal pore size (GF-75, Advantec) were used. About $68.7-84.9 \%$ of the bacterial cells were retained on the GF75 filter (data not shown). One to $2 \mathrm{~L}$ of water samples were filtered through precombusted $\left(450^{\circ} \mathrm{C}, 5 \mathrm{~h}\right) \mathrm{GF} 75$ filters. POC concentrations were measured using a CN corder (MT-700; Yanako). The contribution of calcium carbonate to the particulate carbon concentration was ignored because particulate calcium concentrations are 
typically low in the study area (Mito et al, 2002).

\section{$R Q$ analysis}

Water samples were filtered through the GMF2UM glass fiber filters (Whatman) to remove large particles such as phytoplankton and zooplankton, and the filtrates were filtered again through 0.2- $\mu \mathrm{m}$ Teflon filters (Advantec) to retain bacteria-sized particles. About $97.2-99.9 \%$ of bacterial cells passed through the GMF2UM filter (data not shown).

The RQ concentrations were determined using a modified method as previously described by Kunihiro et al. $(2008,2011)$. Briefly, quinones were extracted from the filters with a chloroform-methanol mixture $(2: 1, \mathrm{v} / \mathrm{v})$ and re-extracted into hexane. UQs and MKs contained in the crude extract were separated and purified on a Sep-Pak ${ }^{\circledR}$ Plus Silica (Waters). The molecular species and concentrations of quinones were determined with a high performance liquid chromatography (HPLC) system equipped with an ODS column (pore size, $3.5 \mu \mathrm{m}$; Eclipse Plus C18, $3.0 \times 150 \mathrm{~mm}$; Agilent) and a photodiode array detector (SPD-M20A; Shimadzu). A mixture of $20 \%$ isopropylether in methanol was used as the mobile phase, at a flow rate of $0.5 \mathrm{~mL} \mathrm{~min}^{-1}$. The column oven temperature was maintained at $35^{\circ} \mathrm{C}$. UQs and MKs were quantified at wavelengths of $275 \mathrm{~nm}$ and $270 \mathrm{~nm}$, respectively. UQ-10 (Sigma) was used as a quantitative standard. The quinones were identified according to their column retention times and the UV spectrum of each peak was observed in the photodiode array detector (Hiraishi and Kato 1999).

In the present paper, we refer to the RQ types using the following abbreviations: ubiquinone, UQ- $n$; menaquinone, MK- $n$. The number $(n)$ indicates the number of isoprene units in the side chain of the quinone. For example, UQ-10 represents a ubiquinone with 10 isoprenoid units, and MK-9 $\left(\mathrm{H}_{2}\right)$ represents a menaquinone with 9 isoprenoid units where 1 of the 9 units is hydrogenated with 2 hydrogen atoms. 


\section{Cluster analysis based on the $R Q$ profiles}

Quantitative evaluation of the changes in the microbial community during the study period was carried out by calculating a dissimilarity index $(D)$ based on the quinone profiling data using the following equation (Hiraishi et al. 1991):

$$
D(i, j)=\frac{1}{2} \sum_{k=1}^{n}\left|f_{k i}-f_{k j}\right|
$$

where $f_{k i}$ and $f_{k j}$ are the mole fractions of the $k$ quinone component in the $i$ and $j$ samples, respectively. The distance matrix was used for cluster analysis.

The between-groups linkage method was used for cluster formation with the aid of the KyPlot 5.0 program (KyensLab Inc.).

\section{Cultures}

Bacterial strains and a mixture of culturable bacteria were used to analyze the differences in carbon yields of RQs between UQ- and MK-containing bacteria. Surface water of the sampling station aged over 6 months in dark following GF/F filtration was used to prepare PYG agar plates $\left(5 \mathrm{~g} \mathrm{~L}^{-1}\right.$ peptone, $2.5 \mathrm{~g} \mathrm{~L}^{-1}$ yeast extract, and $1 \mathrm{~g} \mathrm{~L}^{-1}$ glucose) and 10 times diluted PYG agar plates. One-hundred-microliter aliquots of water samples were spread on these plates and the plates were incubated at $20^{\circ} \mathrm{C}$ for 2 weeks. 4 bacterial strains, namely, $\mathrm{O}$, $\mathrm{P}, \mathrm{Y} 1$, and $\mathrm{Y} 2$ (Table 2) were isolated. While colonies of the strains $\mathrm{O}$ and $\mathrm{P}$ were orange and pink, respectively, the strains $\mathrm{Y} 1$ and $\mathrm{Y} 2$ were yellow with different colony morphologies (Table 2). The isolates were grown axenically in diluted PYG liquid medium at $20^{\circ} \mathrm{C}$ and harvested in the exponential growth phase by filtration (GF75 filter; Advantec).

The culturable bacterial mixture was obtained by inoculating diluted PYG liquid medium with $100 \mu \mathrm{l}$ of water sample collected from the $5 \mathrm{~m}$ depth layer on February 2011. The culturable bacteria were harvested in the same manner as the isolates. Harvested cells were 
used for measuring the concentrations of quinones and POC (see above). The cell number and cell volume were estimated by fixing several milliliters of the culture medium with glutaraldehyde (final concentration, 1\%). Cell-specific carbon content (CSCC), volume-specific carbon content (VSCC), and RQ-specific carbon content (RSCC) were calculated for each culture according to the following equations:

$\operatorname{CSCC}\left(\right.$ fg $\mathrm{C}$ cells $\left.\mathrm{s}^{-1}\right)=\frac{\text { POC in culture }}{\text { Bacterial cell number in culture }}$

$\operatorname{VSCC}\left(\operatorname{pg} \mathrm{C} \mu \mathrm{m}^{-3}\right)=\frac{\text { POC in culture }}{\text { Total bacterial cell volume in culture }}$

$\operatorname{RSCC}\left(\mathrm{mg} \mathrm{C} \mathrm{nmol}^{-1}\right)=\frac{\text { POC in culture }}{\mathrm{RQ} \text { yield from culture }}$

\section{Incubation experiments}

Incubation experiments were conducted to determine bacterial RQ and carbon contents at the sampling site. A water sample was collected at a depth of $5 \mathrm{~m}$ at the sampling site on June 22,2011 , and filtered through $\mathrm{GF} / \mathrm{C}$ glass fiber filters having a nominal pore size of $0.2-\mu \mathrm{m}$ or 1.2- $\mu \mathrm{m}$ (Whatman). The $0.2-\mu \mathrm{m}$ filtrate (microorganism free) and the $1.2-\mu \mathrm{m}$ filtrate (bacterial grazer free) were mixed in a ratio of 9:1 to reduce bacterial density for avoiding depletion of carbon and nutrient source during the incubation and poured into a 6-L polyethylene bag. Glucose was added to each bag at a final concentration of $25 \mu \mathrm{mol} \mathrm{L}{ }^{-1}$ to stimulate bacterial growth. The experiment was run in triplicate, and the experimental bags were incubated in the dark at in-situ temperature. After 5 days of incubation, samples were removed to measure POC concentration, bacterial quinone concentration, bacterial abundance, and cell volume. Samples for POC analysis were collected on precombusted $\left(450^{\circ} \mathrm{C}, 5 \mathrm{~h}\right)$ 
GF75 filters, and the amount of carbon was measured using a CN corder (MT-700; Yanako). CSCC, VSCC, and RSCC were also calculated from the incubation experiment.

\section{Statistical analysis}

Analyses using the Student's t-test and Pearson's coefficient were performed with Microsoft Excel.

\section{Results}

Variation in physico-chemical parameters

Water temperature at $5 \mathrm{~m}$ varied from June to December 2010, whereas water temperature at $70 \mathrm{~m}$ was low and relatively constant throughout the study period (Table 1). Because the differences in water temperature between the $5 \mathrm{~m}$ and $70 \mathrm{~m}$ depths from January to March 2011 were not more than $0.4^{\circ} \mathrm{C}$, June to December 2010 was regarded as the stratification period and January to March 2011 as the mixing period. During the stratification period, DOC, POC, and chlorophyll $a$ concentrations varied at $5 \mathrm{~m}$, whereas at $70 \mathrm{~m}$, all the parameters were relatively low with constant values (Table 1).

Seasonal variation in bacterial number, biovolume, and $R Q$ concentration

During the stratification period, bacterial number and bacterial cell volume at $5 \mathrm{~m}$ varied from $1.4 \times 10^{9}$ to $4.3 \times 10^{9}$ cells $\mathrm{L}^{-1}$ and from 0.16 to $0.77 \mathrm{~mm}^{3} \mathrm{~L}^{-1}$, respectively (Fig. $1 \mathrm{~A}, 1 \mathrm{~B}$ ). In contrast, the bacterial number and bacterial cell volume at $70 \mathrm{~m}$ were less variable $(7.5 \times$ $10^{8}$ to $1.1 \times 10^{9}$ cells $\mathrm{L}^{-1}, 0.10$ to $0.22 \mathrm{~mm}^{3} \mathrm{~L}^{-1}$, respectively). During the late stratification period (November or December) and the mixing period, the differences in bacterial number and cell volume between the $5 \mathrm{~m}$ and $70 \mathrm{~m}$ depths diminished (Fig. 1A, 1B).

At $5 \mathrm{~m}$, the RQ concentration exhibited a variable pattern similar to that of bacterial number throughout the study period (Fig. 1C). RQ concentration at the $5 \mathrm{~m}$ depth gradually decreased from $101.5 \mathrm{pmol} \mathrm{L}^{-1}$ to $13.7 \mathrm{pmol} \mathrm{L}^{-1}$ during the stratification period, whereas that of the $70 \mathrm{~m}$ depth fluctuated between 23.0 and $42.4 \mathrm{pmol} \mathrm{L}^{-1}$. During the mixing period, RQ 
concentration of the $5 \mathrm{~m}$ and $70 \mathrm{~m}$ depths showed similar changing patterns, ranging from 14.0 to 33.0 pmol L $\mathrm{L}^{-1}$ and from 14.7 to $25.6 \mathrm{pmol} \mathrm{L}^{-1}$, respectively.

Significantly, the RQ concentrations at $5 \mathrm{~m}$ and $70 \mathrm{~m}$ depths showed fairly linear relationships with bacterial number $\left(r^{2}=0.74, p<0.001\right)$ and bacterial cell volume $\left(r^{2}=0.94\right.$, $p<0.001$ ) (Fig. 2). When we individually used the data of $5 \mathrm{~m}$ or $70 \mathrm{~m}$ depth, we found a significant correlation only for bacterial number $\left(r^{2}=0.82, p<0.001\right)$ and bacterial cell volume $\left(r^{2}=0.98, p<0.001\right)$ at $5 \mathrm{~m}$ depth was observed (Fig. 2). However, there were no significant correlations at $70 \mathrm{~m}$ depth (Fig. 2).

\section{Seasonal variation in $U Q$ and $M K$ concentrations}

At $5 \mathrm{~m}$, UQ and MK concentrations were the highest in July 2010 and then gradually decreased (Fig. 3A, B). At $70 \mathrm{~m}$, UQ concentrations fluctuated from 9.8 to $18.9 \mathrm{pmol} \mathrm{L}^{-1}$ during the stratification period, whereas the MK concentration was relatively stable. Relative concentration of UQ was generally higher than that of MK at the hypolimnion, whereas the opposite trend was found at $5 \mathrm{~m}$ (Fig. 3C, D).

The major RQ concentrations at both depths showed similar changing patterns with some exceptions (Fig. 4A-F). Generally, the highest values were observed in July or August at $5 \mathrm{~m}$ and tended to decrease toward the mixing period. UQ-8 (Fig. 4A) and MK-9(H $\mathrm{H}_{8}$ (Fig. 4F) were the dominant RQs at $5 \mathrm{~m}$, varying from 3.4 to $24.0 \mathrm{pmol} \mathrm{L}^{-1}$ and from 2.4 to $17.6 \mathrm{pmol}$ $\mathrm{L}^{-1}$, respectively. At $70 \mathrm{~m}$, most of the dominant quinone species did not exhibit any seasonal variability, although UQ-8 highly fluctuated throughout the study period (6.0 to $17.0 \mathrm{pmol}$ $\left.\mathrm{L}^{-1}\right)$ (Fig. 4A).

During the stratification period, the relative concentrations of UQ- 8 at $70 \mathrm{~m} \mathrm{(36 \%} \mathrm{to} 57 \%$; average, 48\%) was much higher than that at $5 \mathrm{~m}$ (24\% to 33\%; average, 29\%) (Fig. 4G). In contrast, the relative concentrations of $\mathrm{MK}-9\left(\mathrm{H}_{8}\right)$ at $5 \mathrm{~m}$ was higher $(15 \%$ to $32 \%$; average, $23 \%)$ than that at $70 \mathrm{~m}(16 \%$ to $17 \%$; average, $17 \%)$ during the stratification period (Fig. $4 \mathrm{~L})$. 
During the mixing period, the relative concentrations of UQ-8 and MK-9 $\left(\mathrm{H}_{8}\right)$ were not significantly different between the $5 \mathrm{~m}$ and $70 \mathrm{~m}$ depths (Fig. 4G, L).

The cluster analysis based on the dissimilarity of the RQ profiles divided the bacterial communities into 3 different groups: Group I ( $5 \mathrm{~m}$, stratification period), Group II (70 m, stratification period), and Group III (5 m and $70 \mathrm{~m}$, mixing period) (Fig. 5). Dissimilarity values less than 0.1 are not recognized as different quinone profiles (Hu et al. 2001). Based on these criteria, bacterial communities of Group I consist of various groups with different types of RQs $(>0.1)$.

The contributions of UQ-8 to the total RQ concentration of Group I, Group II, and Group III were $29 \%, 48 \%$, and $38 \%$, respectively (Fig. 6). Contributions of MK-9 $\left(\mathrm{H}_{8}\right)$ to the total RQ of Group I, Group II, and Group III were 23\%, 7.3\%, and 16\%, respectively (Fig. 6). UQ-9, MK-8( $\left.\mathrm{H}_{2}\right)$, and MK-9 $\left(\mathrm{H}_{6}\right)$ were the dominant RQs in Group I, Group II, and Group III, respectively (Fig. 6).

\section{Variations in carbon content per $R Q$ content from cultures and incubation experiment}

UQ-10 was detected in strains $\mathrm{O}$ and $\mathrm{P}$, whereas strains $\mathrm{Y} 1$ and $\mathrm{Y} 2$ contained MK-6 as the sole RQ (Table 2). UQ-7, UQ-8, UQ-9, and MK-7 were detected in the mixed culture at molar ratios of 3:276:1:1.5 (Table 2). The average CSCC, VSCC, and RSCC were $120 \mathrm{fg} \mathrm{C}$ cell $^{-1}$, $0.17 \mathrm{pg} \mathrm{C} \mu \mathrm{m}^{-3}$, and $0.38 \mathrm{mg} \mathrm{C} \mathrm{nmol}^{-1}$, respectively (Table 2). The coefficients of variation (CV) for CSCC, VSCC, and RSCC were $60 \%, 30 \%$, and $27 \%$, respectively (Table 2). In terms of CV, the RSCC in cultures was less variable than CSCC and VSCC. The RSCC of UQ-10-containing strains (average, $0.48 \mathrm{mg} \mathrm{C} \mathrm{nmol}^{-1}$ ) was high relative to those of MK-6-containing bacteria (average, $0.33 \mathrm{mg} \mathrm{C} \mathrm{nmol}^{-1}$ ). However, the RSCC of the mixed culture with a predominance of UQ-8 (98\%) exhibited a similar value $\left(0.30 \mathrm{mg} \mathrm{C} \mathrm{nmol}^{-1}\right)$ as that of MK-6-containing bacteria. UQ-8, UQ-10, MK-6, MK-7, and MK-10 were detected in the incubation experiment at molar ratios of 27:5:52:7:1. The average CSCC, VSCC, and 
RSCC from the incubation experiment were $42 \mathrm{fg} \mathrm{C} \mathrm{cell}^{-1}, 0.17 \mathrm{pg} \mathrm{C} \mu \mathrm{m}^{-3}$, and $0.67 \mathrm{mg} \mathrm{C}$ $\mathrm{nmol}^{-1}$, respectively.

\section{Discussion}

\section{Bacterial biomass estimation}

The coefficient of determination $\left(r^{2}\right)$ for the relationship between bacterial biovolume and RQ concentration was higher (0.94) than that between bacterial number and RQ concentration (0.74), suggesting that RQ content is a better indicator of bacterial biovolume than bacterial cell number. Thus, RQs can be used for bacterial biomass estimation in Lake Biwa. However, on using the data of $70 \mathrm{~m}$ depth individually, RQ concentration did not correlate with cell number or biovolume (Fig. 2). The annual variation of cell number at $70 \mathrm{~m}$ was much lower $(\mathrm{CV}, 28 \%)$ than that at $5 \mathrm{~m}(\mathrm{CV}, 45 \%)$, while the annual variation of cell-specific RQ concentration at $70 \mathrm{~m}$ was higher $(\mathrm{CV}, 40 \%)$ than that at $5 \mathrm{~m}(\mathrm{CV}, 32 \%)$. A lack of correlation between cell abundance and RQ concentration at $70 \mathrm{~m}$ was probably due to the high variations of cell specific RQ concentration (Fig. 2A). The annual variation of cell volume specific RQ concentration at $70 \mathrm{~m}$ was also much higher $(\mathrm{CV}, 32 \%)$ than that at $5 \mathrm{~m}$ (CV, 14\%). In the hypolimnion of Lake Biwa, the amounts of available nutrients for bacteria are much higher than that of the epilimnion during the stratification period, whereas the supply of labile DOM is limited (Nishimura et al. 2005). Bacterial nucleic acid content is affected by phosphorus concentration in the hypolimnion of Lake Biwa (Nishimura et al. 2005). The bacterial RQ content may be regulated by both the supply of organic substrates and electron acceptors such as oxygen, nitrate, and nitrite, though it is not generally understood.

The reliability of RQs as a tool for estimating bacterial carbon biomass was evaluated by examining RSCC variations in bacterial cells (Table 2). It has been reported previously that 
cell-specific RQ content varies between strains, whereas strong positive correlations between RQs and total cell number have been reported in soil and aquatic environments (Hiraishi et al. 2003). However, our results indicate that RQ concentration was a better indicator of bacterial cell volume than cells number (Fig. 2). Thus, it is likely that the large variation in cell-specific RQ content in previous studies was due to the variability of cell volumes.

The VSCC of freshwater bacteria in previous studies varied depending on environmental conditions and bacterial activity (Nagata 1986; Bjørnsen 1986; Nagata and Watanabe 1990; Kroer 1994; Loferer-Krößbacher et al. 1998). As differences in measurement techniques and representativeness of the average cell volume derived from a limited number of cell size measurements may result in different estimates, in contrast, the variation in RSCC in the present study was small (Table 2). The RQ measurement can predict bacterial carbon biomass with at least equally good precision, compared to image analysis-based measurement of bacterial biovolume.

However, In contrast to estimations by image analysis, bacterial RQ analysis by HPLC provides a less laborious way for simultaneous determination of bacterial biomass and composition. About one day could be sufficient to analyze about 20 samples if the HPLC is equipped with an autosampler, though the sample preparations are needed before the HPLC analysis.

\section{Bacterial carbon concentration estimated by $R Q$ concentration}

Individual strains grown in an artificial medium showed wide ranges of both VSCC and RSCC (Table 2). As far as our knowledge goes, only a single report on RSCC value in natural

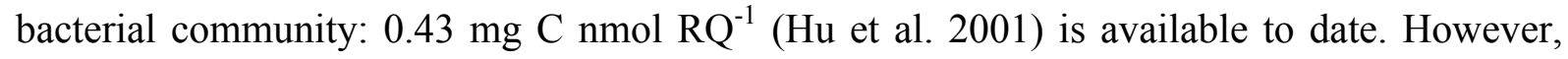
this value was derived from activated sludge samples, and the RSCC values of bacterial communities in lakes have never been estimated. The RSCC value in the present study, therefore, is the first estimation for planktonic bacterial biomass. The RSCC value calculated 


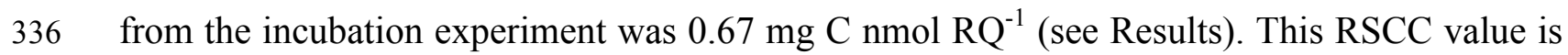
the highest amongst the values from the strains and previous estimates, and bacterial carbon biomass estimation based on RQ concentration would carry an error ranging from 0.27 to 0.67 mg C nmol RQ ${ }^{-1}$ (Table. 2). However, larger variations of VSCC estimated from image analysis have been reported in a previous study and exhibited 5 fold differences within 9 analyses from natural bacterial assemblages in Lake Biwa (Nagata 1986). Such a large variation of VSCC from natural bacteria has been reported in many studies (Bjørnsen 1986, Nagata and Watanabe 1990, Kroer 1994). Thus, the estimated range of RSCC in this study is rather small, compared to the range displayed by VSCC determined by image analyses. The bacterial community composition in our incubation experiment was dominated by UQ-8, similar to natural bacterial community in the lake. Hence, the RSCC value from the natural bacterial community thus determined was used as the conversion factor for estimating planktonic bacterial carbon biomass according to the following equations: Carbon biomass $\left(\mathrm{mg} \mathrm{C} \mathrm{l^{-1 }}\right)=0.67 \times \mathrm{RQ}$ concentration $\left(\right.$ pmol L $\left.\mathrm{L}^{-1}\right)$. During the study period, the carbon biomasses of bacteria ranged from 0.008 to $0.054 \mathrm{mg} \mathrm{C} \mathrm{L}^{-1}$ at $5 \mathrm{~m}$, and from 0.010 to 0.024 $\mathrm{mg} \mathrm{C} \mathrm{L}^{-1}$ at $70 \mathrm{~m}$ (Table 3). Contributions of bacterial biomass to the total POC concentration at the $5 \mathrm{~m}$ and $70 \mathrm{~m}$ depths were from $3.1 \%$ to $7.1 \%$ (average: $4.7 \%$ ) and from $1.9 \%$ to $10 \%$ (average: 7.4\%), respectively (Table 3). Using D-amino acids as bacteria-specific biomarkers, Kawasaki et al. (2011) estimated the living bacterial contribution to POC in surface waters of North Pacific Gyre as 5.2-8.2\%, which is close to the value estimated in the present study.

There are potential sources of error in the current estimation of carbon biomass. The conversion factor determined in the present study may still be an overestimation due to the presence of nonliving colloidal and submicron particles (Koike et al. 1990; Kaiser and Benner 2008), and bacterial release of nonliving detrital particles in the bacterial size fraction (Kawasaki and Benner 2006; Kawasaki et al. 2011). Further examination of the relationship 
between bacterial carbon content and RQ content is needed for more reliable bacterial carbon estimation.

\section{Succession of bacterial community structure}

As there was no significant difference between RSCC of UQ-containing bacteria and that of MK-containing bacteria (Table 2), it could be assumed that RSCC would be fairly constant independent of the RQ types, and the relative concentration of individual RQ could be used as an indicator of relative biomass of individual RQ containing bacteria. Moreover, since RQs can be regarded as a specific biomarker for discriminating bacterial subgroups with different types of energy metabolism, Group I comprised highly diverse communities $(>0.1)$ in terms of metabolic state. Group II could be further divided into several groups, although dissimilarity values were less variable than that of Group I. Bacterial communities of Group III fell into a small cluster $(<0.1)$, except for the bacterial community at the $5 \mathrm{~m}$ depth in March 2011. Thus, bacterial communities of Group III are relatively uniform assemblages, suggesting that the metabolic state of bacterial communities in Group III at both the depths came similar during the mixing period.

The relative abundances of UQ-8 and MK-9 $\left(\mathrm{H}_{8}\right)$ varied among the groups (Fig. 4G, 4L) and there appear to be 2 major determinants for dividing the 3 groups in the dendrogram (Fig. 5). Bacteria with these RQs may be susceptible to changes in certain physicochemical parameters caused by water mixing and may become opportunistically dominant (Fig. 6). Chemical and biological parameters, such as DOC and chlorophyll $a$ (Table 1), were almost uniformly distributed by vertical water mixing (Table 1). RQ compositions at the 2 depths also became similar during the mixing period (Fig. 5). These results suggest that bacterial groups with different types of RQs shifted due to changes in physicochemical parameters caused by vertical water mixing.

The predominant UQ-8-containing bacteria exhibited a unique oscillation pattern 
particularly at $70 \mathrm{~m}$ throughout the study period (Fig. 4A, 4G). A broad corresponding relationship was observed between phylogenetic assignment of bacteria and dominant RQ (Collins and Jones 1981; Hiraishi 1999). Betaproteobacteria, which is one of the major phylogenetic bacterial groups in freshwater systems (Glöckner et al. 1999), mostly contains UQ-8 as the dominant RQ (Hiraishi 1999). UQ-8-containing bacteria have been associated with nitrogen dynamics (Sinha and Annachhatre 2007; Hamada et al. 2010), and most nitrifying, ammonia-oxidizing- and/or nitrate-oxidizing bacteria belong to this group (Lim et al. 2004; Sinha and Annachhatre 2007). A good correlation between UQ-8 concentration and nitrite + nitrate concentration $\left(r^{2}=0.84, n=8, p<0.01\right)$ was found in the present study, although only limited data on nitrite and nitrate concentrations were available from December 2010 to March 2011 (S.D. Thottathil, unpublished data). In general, UQs are preferably produced by the nitrate respiratory types with relatively high potential electron acceptors. Particularly, UQ-8-containing bacteria may preferentially use nitrate as the final electron acceptor. However, it remains unclear whether UQ-8 is preferentially used for nitrate and nitrite respiration under oxygenated conditions, as in the hypolimnion of Lake Biwa where the annual minimum concentration of hypolimnetic dissolved oxygen is up to $3.2 \mathrm{mg} \mathrm{L}^{-1}$ (Kim et al. 2006).

\section{Conclusion}

To the best of our knowledge, this is the first study that demonstrates the utility of RQ analysis in planktonic bacterial biomass estimation. The results yielded reliable values for carbon concentration and valuable information regarding bacterial contributions to POC. Although the relative abundance of each RQ shifted due to the changes in physicochemical parameters caused by vertical water mixing, UQ-8 dominated the total RQ concentration throughout the study period and accounted for up to $57 \%$ of the total RQ concentration. Elucidation of the relationship between biomass of the major bacterial groups, such as UQ-8 
411 containing bacteria, and environmental variables, along with estimation of the growth and

412 mortality of those bacterial groups in future studies may provide insights into the regulation of 413 carbon cycling by bacteria.

414

\section{Acknowledgments}

416 The authors would like to thank Mr. Tadatoshi Koitabashi and Dr. Yukiko Goda for their

417 assistance during field sampling, and Dr. Naoto F. Ishikawa and Mr. Yusuke Okazaki for their 418 assistance with sample analyses as well as their encouragement throughout this study. We are 419 grateful to the handling editor, Dr. Hisaya Kojima, and two anonymous reviewers whose 420 comments greatly improved the manuscript. We also thank Drs. Masayuki Ushio, Taichi 421 Yokokawa, Ryuji Kondo, Fereidoun Rassoulzadegan, and other colleagues at the Center for Ecological Research, Kyoto University for their valuable comments on this study. This study was partly supported by JSPS KAKENHI Grant Number 23370010 to S.N. and 21710081 , 


\section{References}

Azam F, Malfatti F (2007) Microbial structuring of marine ecosystems. Nature Rev 5:782-791. doi: 10.1038/nrmicro 1747

Bjørsen PK (1986) Automatic determination of bacterioplankton biomass by image analysis. Appl Environ Microbiol 51:1199-1204.

Blackburn N, Hagström Å, Wikner J, Cuadros-Hansson R, Bjørsen PK (1998) Rapid determination of bacterial abundance, biovolume, morphology, and growth by neural network-based image analysis. Appl Environ Microbiol 64:3246-3255

Collins MD, Jones D (1981) Distribution of isoprenoid quinone structural types in bacteria and their taxonomic implications. Microbiol Rev 45:316-354

Ducklow HW (2000) Bacterial production and biomass in the oceans, In: Kirchman DL (ed) Microbial ecology of the oceans. Wiley, pp. 85-120

Gasol JM, Zweifel UL, Peters F, Fuhrman JA, Hagstrom A (1999) Significance of size and nucleic acid content heterogeneity as measured by flow cytometry in natural planktonic bacteria. Appl Environ Microbiol 65:4475-4483

Glöckner FO, Fuchs BM, Amann R. (1999) Bacterioplankton compositions of lakes and oceans: a first comparison based on fluorescence in situ hybridization. Appl Environ Microbiol 65:3721-3726

Glöckner FO, Zaichikov E, Belkova N, Denissova L, Pernthaler J, Pernthaler A, Amann R (2000) Comparative 16S rRNA analysis of lake bacterioplankton reveals globally distributed phylogenetic clusters including an abundant group of Actinobacteria. Appl Environ Microbiol 66:5053-5065. doi: 10.1128/AEM.66.11.5053-5065.2000

Hamada K, Miura A, Fujita M, Hitomi T, Kubota T, Shiratani E (2010) Evaluation of the characteristics of microorganisms that contribute to denitrification in the paddy drainage 
treatment apparatus by quinone composition measurement. J Water \& Environ Tech 8:421-427. doi: 10.2965/jwet.2010.421

Hedrick DB, White DC (1986) Microbial respiratory quinones in the environment. J Microbiol Meth 5:243-254. doi: 10.1016/0167-7012(86)90049-7

Hiraishi A, Morishima Y, Takeuchi J (1991) Numerical analysis of lipoquinone patterns in monitoring bacterial community dynamics in wastewater treatment systems. J Gen Appl Microbiol 37:57-70

Hiraishi A (1999) Isoprenoid quinones as biomarkers of microbial populations in the environment. J Biosci Bioeng 88:449-460. doi: 10.1016/S1389-1723(00)87658-6

Hiraishi A, Kato K (1999) Quinone profiles in lake sediments: Implications for microbial diversity and community structures. J Gen Appl Microbiol 45:221-227. doi: $10.2323 /$ jgam.45.221

Hiraishi A, Iwasaki M, Kawagishi T, Yoshida N, Narihiro T, Kato K. (2003) Significance of lipoquinones as quantitative biomarkers of bacterial populations in the environment. Microbes Environ 18: 89-93. doi: 10.1264/jsme2.18.89

Hu H-Y, Lim B-R, Goto N, Fujie K (2001) Analytical precision and repeatability of respiratory quinones for quantitative study of microbial community structure in environmental samples. J Microbiol Meth 47:17-24. doi: $10.1016 / \mathrm{S} 0167-7012(01) 00286-\mathrm{X}$

Kaiser K, Benner R (2008) Major bacterial contribution to the ocean reservoir of detrital organic carbon and nitrogen. Limnol Oceanogr 53:99-112. doi: 10.4319/lo.2008.53.1.0099

Kawasaki N, Benner R (2006) Bacterial release of dissolved organic matter during cell growth and decline: Molecular origin and composition. Limnol Oceanogr 51:2170-2180. doi: $10.4319 / 10.2006 .51 .5 .2170$ 
Kawasaki N, Fukuda R, Ogawa H, Nagata T, Benner R (2011) Bacterial carbon content and the living and detrital bacterial contributions to suspended particulate organic carbon in the North Pacific Ocean. Aquat Microb Ecol 62:165-176. doi: 10.3354/ame01462

Kim C, Nishimura Y, Nagata T (2006) Role of dissolved organic matter in hypolimnetic mineralization of carbon and nitrogen in a large, monomictic lake. Limnol Oceanogr 51:70-78. doi: 10.4319/1o.2006.51.1.0070

Kirchman DL, Ditel AI, Findlay SEG, Fischer D (2004) Changes in bacterial activity and community structure in response to dissolved organic matter in the Hudson River, New York. Aquat Microb Ecol 35:243-257. doi:10.3354/ame035243

Koike I, Hara S, Terauchi K, Kogure K (1990) Role of sub-micrometer particles in the ocean. Nature 345:242-244. doi: 10.1038/345242a0

Kroer N (1994) Relationships between biovolume and carbon and nitrogen content of bacterioplankton. FEMS Microb Ecol 13:217-224

Kunihiro T, Miyazaki T, Uramoto Y, Kinoshita K, Inoue A, Tamaki S, Hama D, Tsutsumi H, Ohwada K (2008) The succession of microbial community in the organic rich fish-farm sediment during bioremediation by introducing artificially mass-cultured colonies of a small polychaete, Capitella sp. I. Mar Pollt Bull 57:68-77. doi: 10.1016/j.marpolbul.2007.10.009

Kunihiro T, Takasu H, Miyazaki T, Uramoto Y, Kinoshita K, Yodnarasri S, Hama D, Wada M, Kogure K, Ohwada K, Tsutsumi H (2011) Increase in Alphaproteobacteria in association with a polychaete, Capitella $\mathrm{sp}$. I, in the organically enriched sediment. The ISME J 5:1818-1831. doi: 10.1038/ismej.2011.57

Langenheder S, Lindström ES, Tranvik LJ (2005) Weak coupling between community composition and functioning of aquatic bacteria. Limnol Oceanogr 50:957-967. doi: 10.4319/10.2005.50.3.0957 
Langenheder S, Lindström ES, Tranvik LJ (2006) Structure and function of bacterial communities emerging from different sources under identical conditions. Appl Environ Microbiol 72:212-220

Li Y (2010) Microbial respiratory quinones as indicator of ecophysiological redox conditions. Front Earth Sci China 4:195-204. doi: 10.1007/s11707-010-0019-3

Lim B-R, Ahn K-H, Songprasert P, Lee S-H, Kim M-J (2004) Microbial community structure in an intermittently aerated submerged membrane bioreactor treating domestic wastewater. Desalination 161:145-153. doi: 10.1016/S0011-9164(04)90050-1

Loferer-Krößbacher M, Klima J, Psenner R (1998) Determination of bacterial cell dry mass by transmission electron microscopy and densitometric image analysis. Appl Enviorn Microbiol 64:688-694

Mito S, Kawashima M, Sohrin Y (2002) Characterization of suspended solids in Lake Biwa by measuring their elemental composition of $\mathrm{Al}, \mathrm{Si}, \mathrm{P}, \mathrm{S}, \mathrm{K}, \mathrm{Ca}, \mathrm{Ti}, \mathrm{Mn}$, and Fe. Limnology 3:11-19. doi: 10.1007/s102010200001

Moran R, Porath D (1980) Chlorophyll determination in intact tissues using $N, N$-Dimethylformamide. Plant Physiol 65:478-479

Nagata T (1986) Carbon and nitrogen content of natural planktonic bacteria. Appl Environ Microbiol 52:28-32

Nagata T, Watanabe Y (1990) Carbon- and nitrogen-to-volume ratios of bacterioplankton grown under different nutritional conditions. Appl Environ Microbiol 56:1303-1309

Nakano S, Kawabata Z (2000) Changes in cell volume of bacteria and heterotrophic nanoflagellates in a hypereutrophic pond. Hydrobiologia. 428:197-203. doi: 10.1023/A:1003971516725

Nishimura Y, Kim C, Nagata T (2005) Vertical and Seasonal Variations of Bacterioplankton subgroups with different nucleic acid contents: possible regulation by phosphorus. Appl. 
Microbiol. 71:5828-5836. doi: 10.1128/AEM.71.10.5828-5836.2005

Porter KG, Feig YS (1980) The use of DAPI for identifying and counting aquatic microflora. Limnol Oceanogr 25:943-948. doi: 10.4319/1o.1980.25.5.0943

Posch T, Loferer-Krößbacher M, Gao G, Alfreider A, Pernthaler J, Psenner R (2001) Precision of bacterioplankton biomass determination: a comparison of two fluorescent dyes, and of allometric and linear volume-to-carbon conversion factors. Aquat Microb Ecol 25:55-63. doi: 10.3354/ame025055

Posch T, Franzoi J, Prader M, Salcher MM (2009) New image analysis tool to study biomass and morphotypes of three major bacterioplankton groups in an alpine lake. Aquat Microb Ecol 54:113-126. doi: 10.3354/ame01269

Saitou K, Nagasaki K, Yamakawa H, Hu H.-Y, Fujie K (1999) Linear relation between the amount of respiratory quinones and the microbial biomass in soil. Soil Sci Plant Nutr 45:775-778. doi: 10.1080/00380768.1999.10415843

Sinha B, Annachhatre AP (2007) Assessment of partial nitrification reactor performance through microbial population shift using quinone profile, FISH and SEM. Bioresour Technol 98:3602-3610. doi: 10.1016/j.biortech.2006.11.034

Straza TRA, Cottrell MT, Ducklow HW, Kirchman DL (2009) Geographic and phylogenetic variation in bacterial biovolume as revealed by protein and nucleic acid staining. Appl Environ Microbiol 75:4028-4034. doi: 10.1128/AEM.00183-09

Takasu H, Kunihiro T, Nakano S (2012) Vertical community structure of bacterial and phytoplankton in Lake Biwa using respiratory quinone and pigment analysis. In: M. Kawaguchi, K. Misaki, H. Sato, T. Yokokawa, T. Itai, T.M. Nguyen, J. Ono and S. Tanabe (ed), Interdisciplinary Studies on Environmental Chemistry-Advanced Environmental Studies by Young Scientists, Terrapub. pp 377-385

Troussellier M. (1997) Variation of carbon content among bacterial species under starvation 
condition. Aquat Microb Ecol 13:113-119. doi: 10.3354/ame013113

554 Villanueva L, Navarrete A, Urmeneta J, Geyer R, White DC, Guerrero R (2007) Monitoring diel variations of physiological status and bacterial diversity in an estuarine microbial mat: an integrated biomarker analysis.

Microbiol Ecol $54: 523-531$.

doi: $10.1007 / \mathrm{s} 00248-007-9224-3$

Yokokawa T, Nagata T, Cottrell MT, Kirchman DL (2004) Growth rate of the major phylogenetic bacterial groups in the Delaware estary. Limnol Oceanogr 49:1620-1629. doi: 10.4319/1o.2004.49.5.1620

561

Yokokawa T, Nagata T (2005) Growth and grazing mortality rates of phylogenetic groups of bacterioplankton in coastal marine environments. Appl Environ Microbiol 71:6799-6807. doi: 10.1128/AEM.71.11.6799-6807.2005

Yokokawa T, Nagata T (2010) Linking bacterial community structure to carbon fluxes in marine environments. J Oceanogr 66:1-12. doi: 10.1007/s10872-010-0001-4 
572 Table 1. Summary of variability in physico-chemical parameters

\begin{tabular}{|c|c|c|c|}
\hline Parameters & $\begin{array}{l}\text { Stratification } \\
\qquad(5 \mathrm{~m})\end{array}$ & $\begin{array}{c}\text { Stratification } \\
\qquad(70 \mathrm{~m})\end{array}$ & $\begin{array}{c}\text { Mixing } \\
(5 \mathrm{~m} \mathrm{\&} 70 \mathrm{~m})\end{array}$ \\
\hline Water temperature $\left({ }^{\circ} \mathrm{C}\right)$ & $22.5 \pm 6.6$ & $8.2 \pm 0.1$ & $7.7 \pm 0.6$ \\
\hline $\mathrm{DOC}\left(\mathrm{mg} \mathrm{C} \mathrm{L}^{-1}\right)$ & $1.18 \pm 0.07$ & $0.93 \pm 0.06$ & $0.93 \pm 0.01$ \\
\hline POC $\left(\mathrm{mg} \mathrm{C} \mathrm{L}^{-1}\right)$ & $0.45 \pm 0.30^{\mathrm{a}}$ & $0.20 \pm 0.04^{b}$ & $0.22 \pm 0.02^{\mathrm{c}}$ \\
\hline Chlorophyll $a\left(\mu \mathrm{g} \mathrm{L}^{-1}\right)$ & $4.92 \pm 3.81$ & $0.30 \pm 0.10$ & $0.31 \pm 0.88$ \\
\hline
\end{tabular}

573

574

575

576

577

578

579

Abbreviations: DOC, dissolved organic carbon; POC, particulate organic carbon.

${ }^{a}$ Values are from October to December $2010(\mathrm{n}=3)$.

${ }^{b}$ Values are September, November and December $2010(n=3)$.

${ }^{c}$ Values from $70 \mathrm{~m}$ on March 2010 were not available due to a laboratory accident. 
Table 2. Carbon yields of bacteria and RQs from culturable bacteria

\begin{tabular}{|c|c|c|c|c|c|c|}
\hline Culture & $\begin{array}{l}\text { Colony } \\
\text { features }\end{array}$ & $\begin{array}{l}\text { Average cell } \\
\text { sizes }\left(\mu \mathrm{m}^{3}\right)\end{array}$ & Detected RQs & $\begin{array}{c}\text { CSCC } \\
\left(\text { fg C cell }^{-1}\right)\end{array}$ & 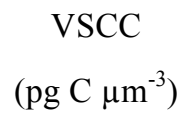 & $\begin{array}{c}\text { RSCC } \\
\left(\mathrm{mg} \mathrm{C} \mathrm{nmol}^{-1}\right)\end{array}$ \\
\hline Strain $O$ & Orange, Small & 0.62 & UQ-10 & 150 & 0.24 & 0.43 \\
\hline Strain P & Pink, Small & 1.3 & UQ-10 & 220 & 0.17 & 0.52 \\
\hline Strain Y1 & Yellow, Small & 0.54 & MK-6 & 54 & 0.10 & 0.27 \\
\hline Strain Y2 & Yellow, Large & 0.71 & MK-6 & 120 & 0.17 & 0.39 \\
\hline Mix & - & 0.28 & $\begin{array}{l}\text { UQ-7: 8: 9: MK-7 } \\
=3: 276: 1: 1.5\end{array}$ & 46 & 0.17 & 0.30 \\
\hline Average & & & & 120 & 0.17 & 0.38 \\
\hline SD & & & & 70 & 0.05 & 0.10 \\
\hline CV (\%) & & & & 60 & 30 & 27 \\
\hline
\end{tabular}

Abbreviations: CSCC, cell-specific carbon content; VSCC, volume-specific carbon content;

RSCC, RQ-specific carbon content. 
604

605

Table 3. Ranges of the estimated contributions of bacteria to POC

\begin{tabular}{lcc}
\hline & $5 \mathrm{~m}$ & $70 \mathrm{~m}$ \\
\hline Bacterial C $\left(\mathrm{mg} \mathrm{C} \mathrm{L}^{-1}\right)^{a}$ & $0.008-0.054$ & $0.010-0.024$ \\
& $(0.025)$ & $(0.015)$ \\
Contribution to total POC $(\%)^{b}$ & $3.1-7.1$ & $1.9-10$ \\
& $(4.7)$ & $(7.4)$ \\
\hline
\end{tabular}

606 Abbreviations as in Table 1.

607 The values provided in parentheses are the average values.

$608{ }^{a}$ Values are from June 2010 to March $2011(\mathrm{n}=10[5 \mathrm{~m}]$ and $11[70 \mathrm{~m}])$.

$609{ }^{b}$ Values are from September 2010 to March $2011(\mathrm{n}=7[5 \mathrm{~m}]$ and $6[70 \mathrm{~m}])$.

610

611

612

613 


\section{Figure legends}

616 Fig. 1. Seasonal variations in (A) bacterial number, (B) bacterial biovolume, and (C) 617 respiratory quinone concentration.

618 Fig. 2. Relationships between (A) bacterial number and RQ concentration and (B) bacterial 619 biovolume and RQ concentration.

620 Fig. 3. Concentrations of (A) UQ, (B) MK, relative concentrations of (C) UQ and (D) MK at 621 water depths of $5 \mathrm{~m}$ and $70 \mathrm{~m}$.

622 Fig. 4. Changes in the concentrations of (A) UQ-8, (B) UQ-10, (C) MK-7, (D) MK-8, (E) 623 MK-9, and (F) MK-9( $\left.\mathrm{H}_{8}\right)$. Changes in the relative concentrations of (G) UQ-8, (H) UQ-10, (I) 624 MK-7, (J) MK-8, (K) MK-9, and (L) MK-9(H $\mathrm{H}_{8}$. Plots at July 2010 are modified from Takasu 625 et al. (2012).

626 Fig. 5. Cluster analysis of the dissimilarity value matrix data from mole fractions of RQs.

627 Fig. 6. RQ compositions of Groups I, II, and III. 

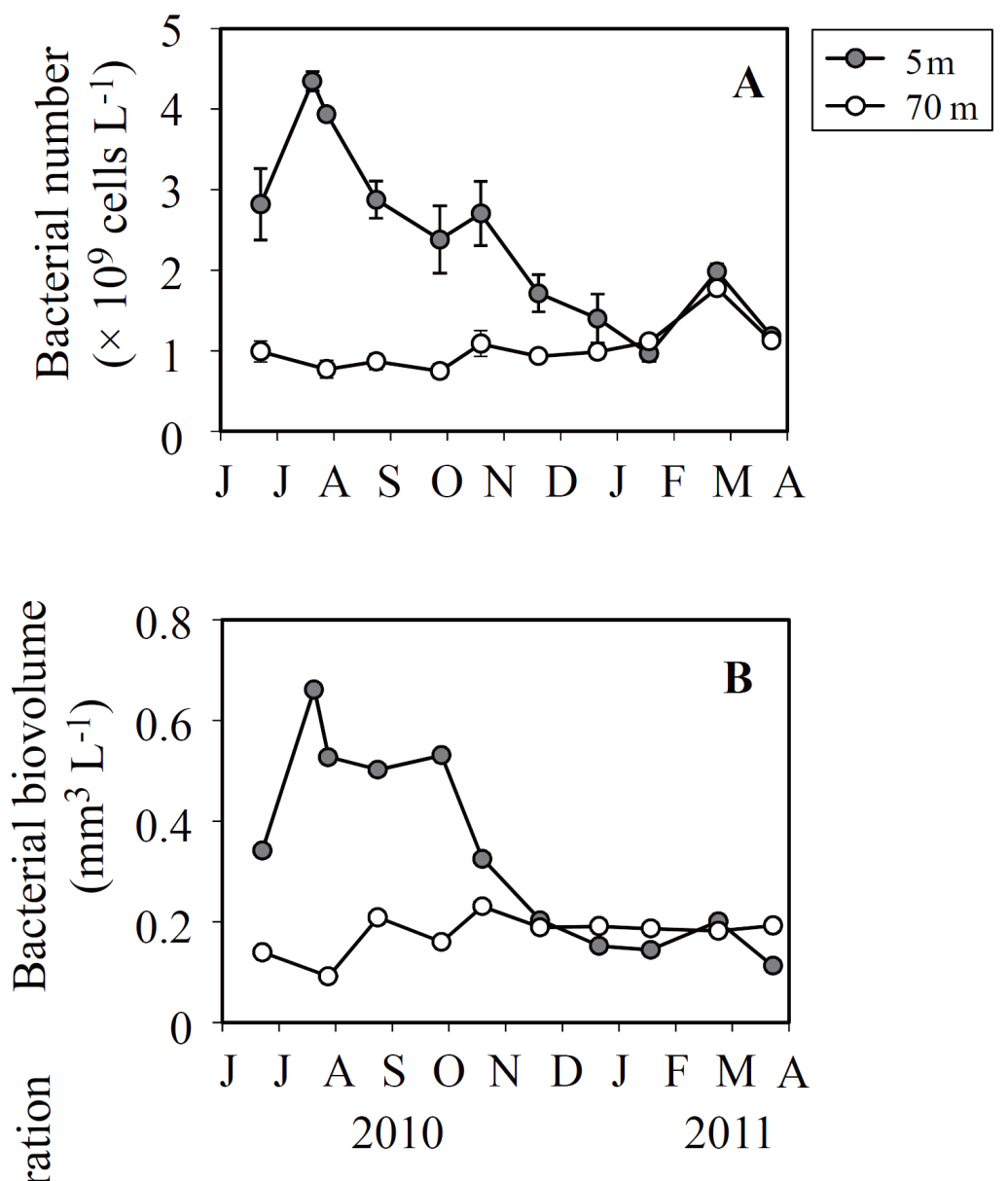
637

638

639

640
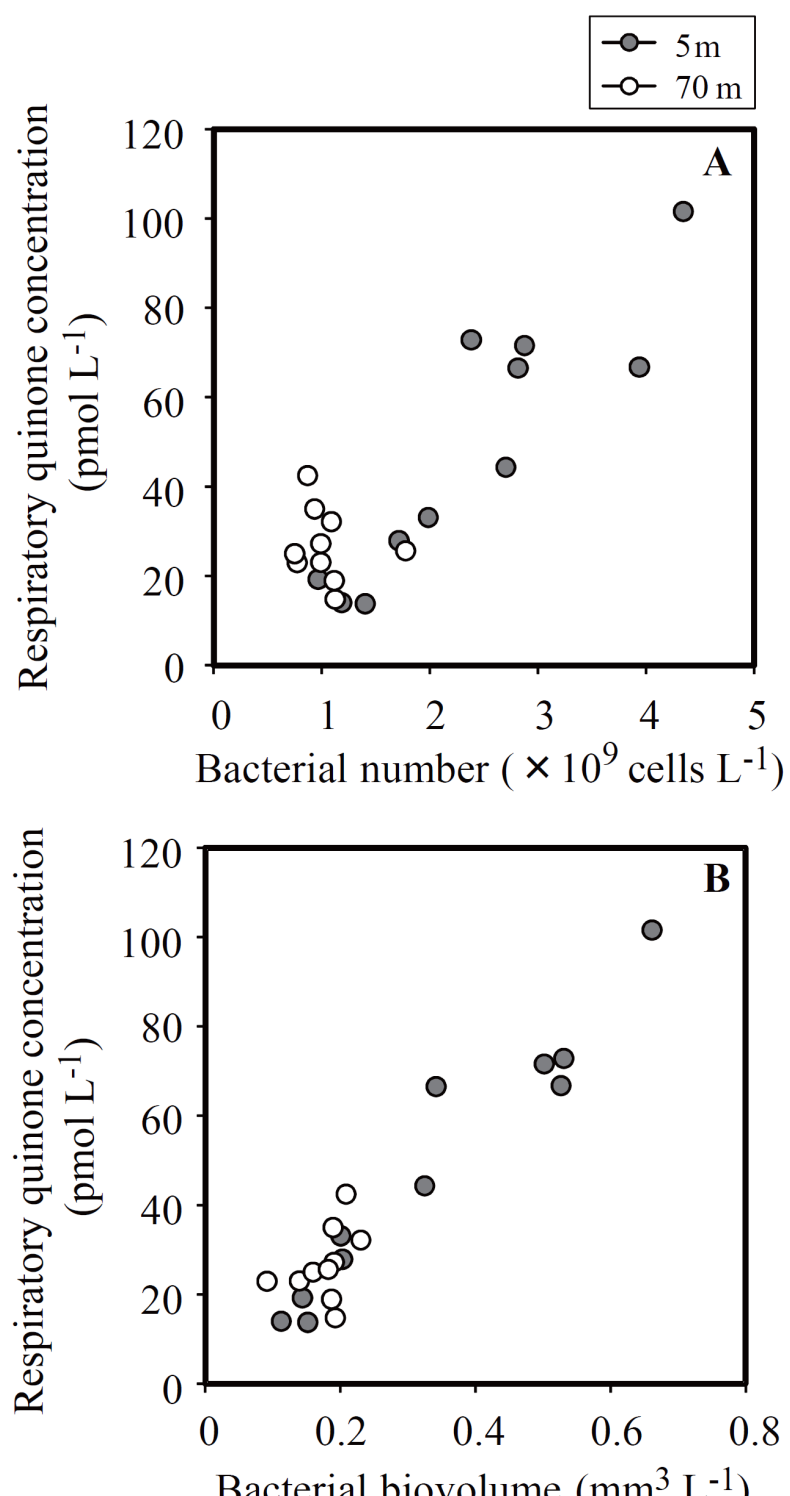

641 Bacterial biovolume $\left(\mathrm{mm}^{3} \mathrm{~L}^{-1}\right)$ 


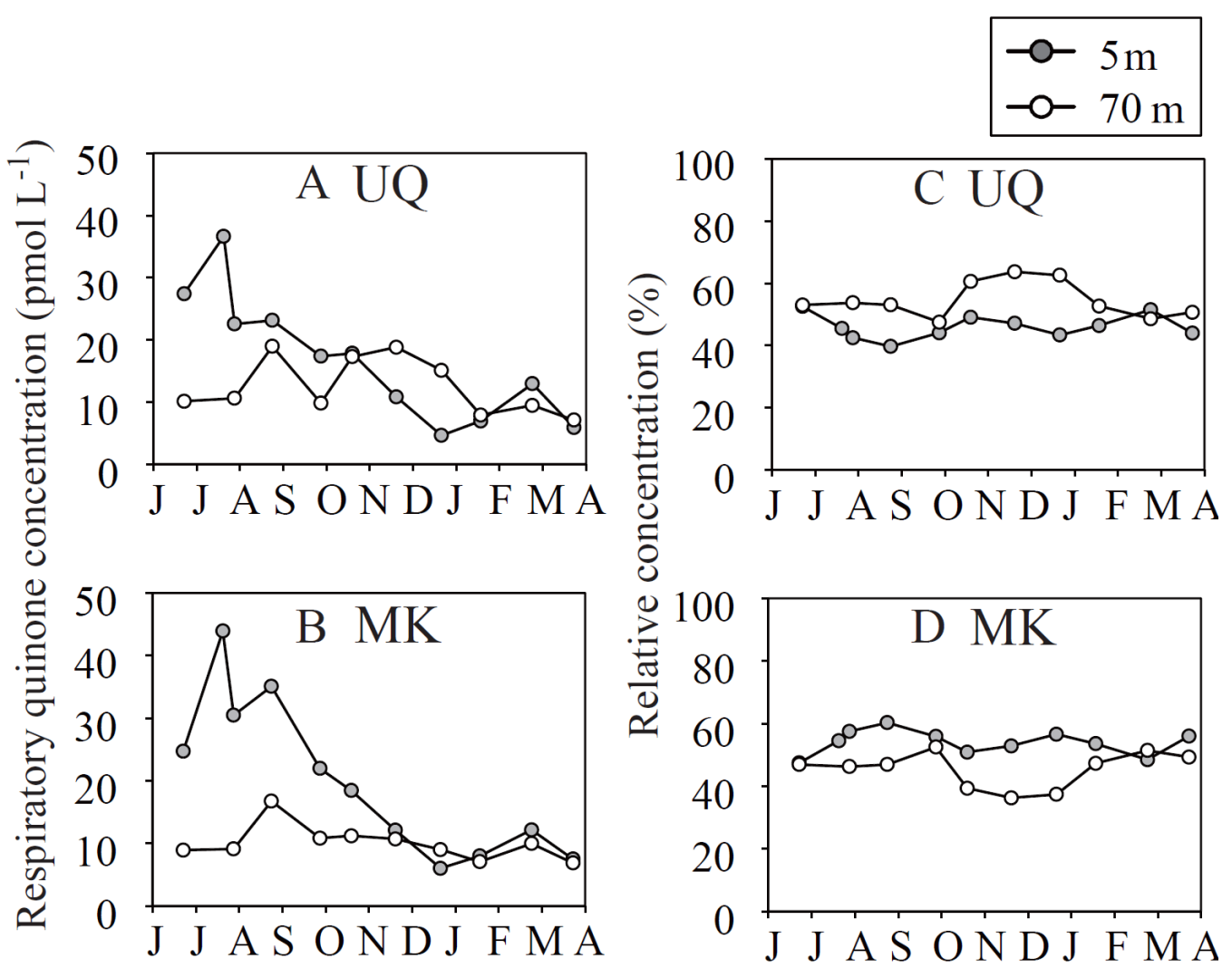



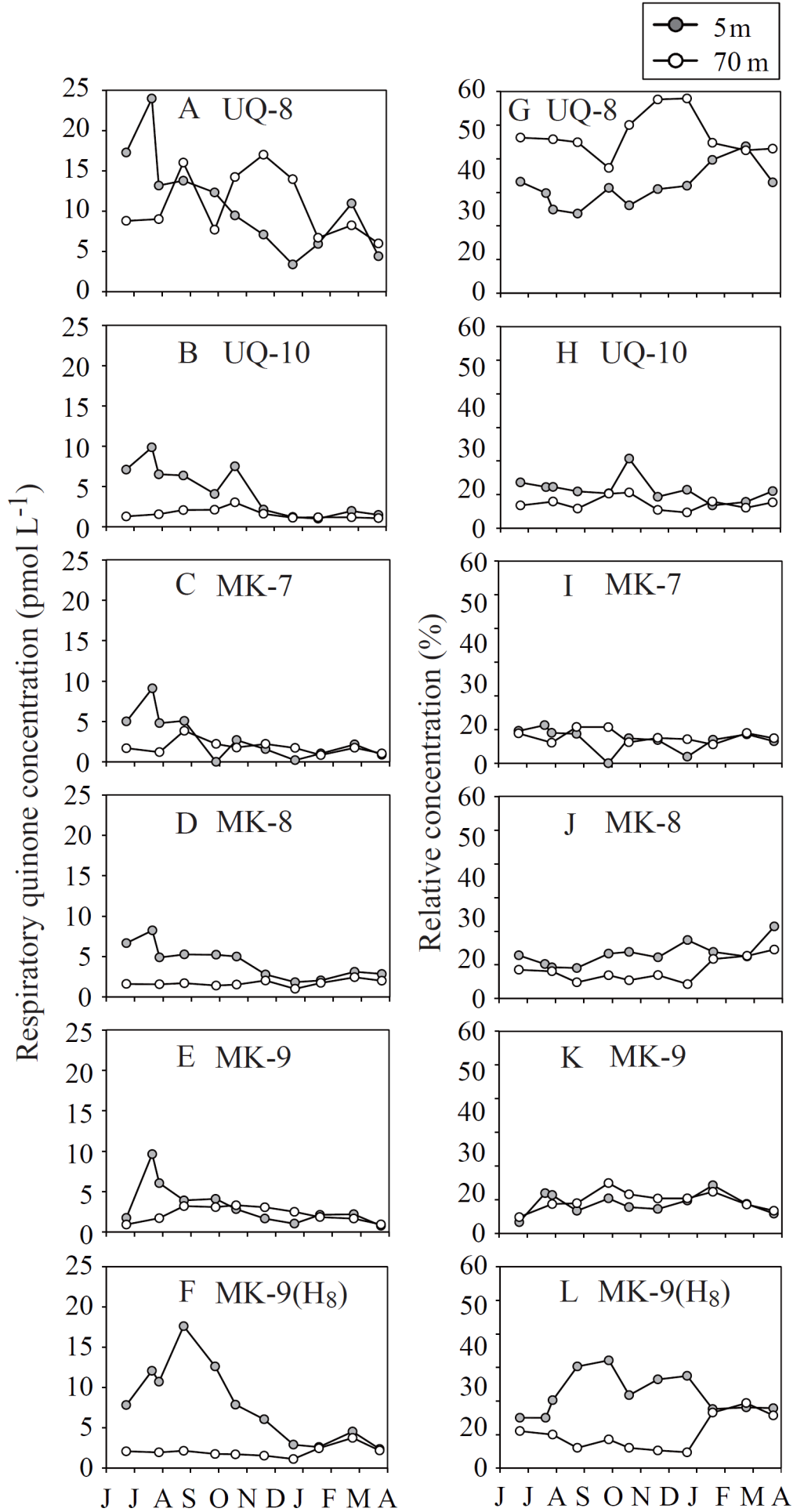


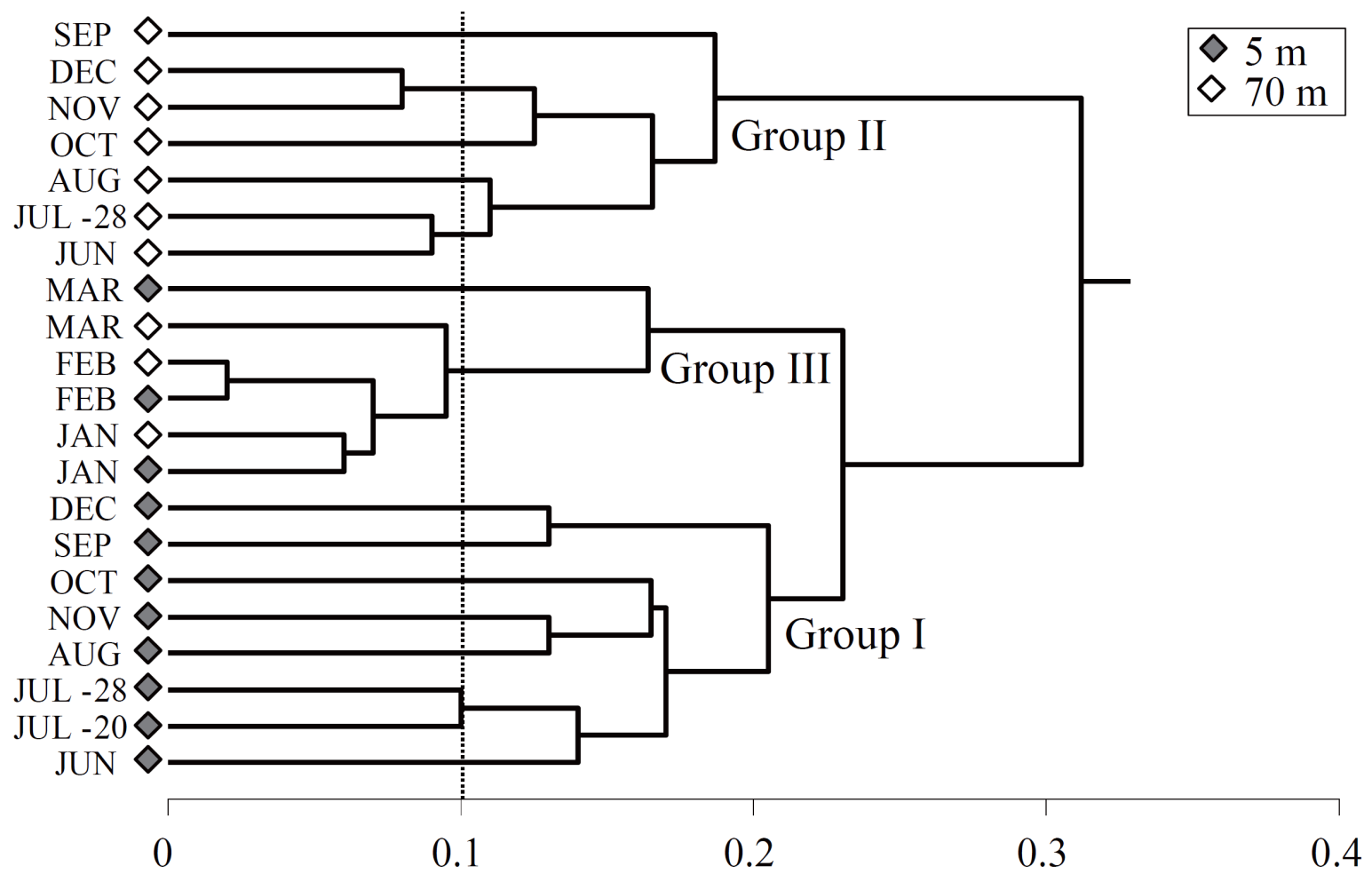


